\title{
A MEDITÁCIÓ EGÉSZSÉGRE GYAKOROLT JÓTÉKONY HATÁSAI ÉS A NEVELÉSI, OKTATÁSI ÖSSZEFÜGGÉSEI A PÁLYAMOTIVÁCIÓ ÉS A KARRIERCÉLOK VONATKOZÁSÁBAN
}

\author{
THE BENEFICENT EFFECTS OF MEDITATION ON EDUCATION AIMS \\ AND ITS CONTENS REGARDING WORKING MOTIVATION AND CARIEER CHOICE
}

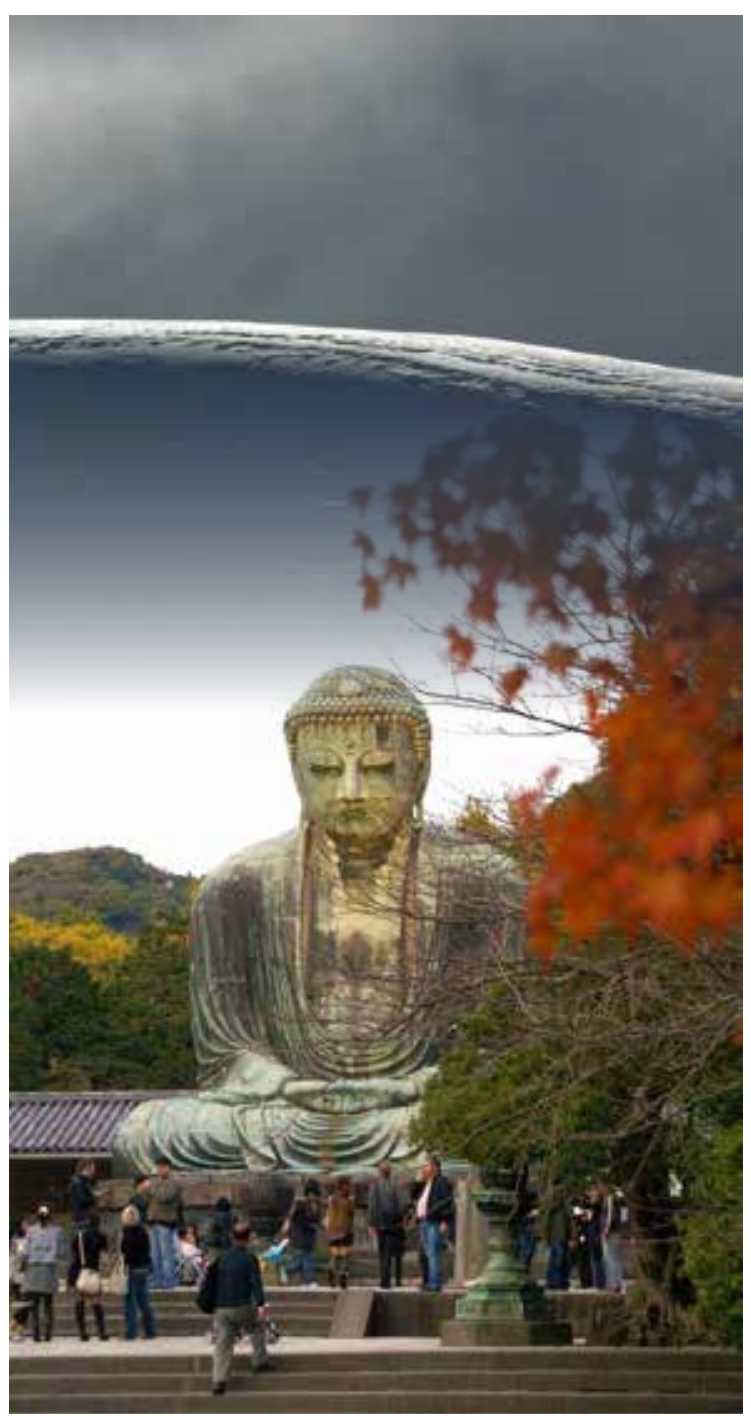

\section{ÖSSZEFOGLĀIÁS}

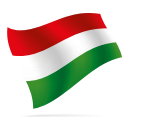
Jelenlegi felgyorsult világunk, mind fizikálisan, mind pedig mentálisan jóval nagyobb terhet ró korunk emberére, mint az elmúlt évszázadokban bármikor. A tartósan fennálló stresszhelyzetek károsíthatják a szervezetet, melynek oldására különböző meditációs technikákat alkalmazhatunk.

Jelenlegi tanulmányban három technikát ismertetünk - egyszerú relaxáció, autogén tréning, progresszív relaxáció zenével -, melyek segítségünkre lehetnek a hétköznapi problémák megoldásában, akár a tanulásban és a munkavégzésben is. Bemutatunk egy érdekes és hatékony technikát, melyet küzdősportok során eredményesen alkalmazhatunk.

A példa jól szemlélteti a meditáció hatásának néhány értékes tulajdonságát, mely támogatja az egyetemekre felvételiző vagy éppen vizsgáikra készülő hallgatók körét éppúgy, mint a pályamotivációt és karriercélok kialakítását.

Kulcsszavak: stresszoldás, egyszerü meditáció, autogén tréning, progresszív meditáció zenére

\section{ABSTRACT}

The accelerated word causes increased load on the population regarding either physical or mental health. The harmful, chronic stress factors have negative effect on human organs. The meditation can solve these injurious progressions.

We present three medication techniques in this study - simple relaxation, autogen training, progressive medication with music - which are effective on treat the everyday problems, the learning and the working process.

An interesting and efficient technique was represented, this useful on combat sport trainings.

This example well reflects the positive effects of motivation, which can be support the students on the entrance exam, or the working motivation and carrier choice.

Key words: stress reduction, simple relax, autogen training, progressive relaxation with music

\section{BEVEZETÉS}

Jelenlegi felgyorsult világunk, mind fizikálisan, mind pedig mentálisan jóval nagyobb terheket ró korunk emberére, mint az elmúlt évszázadokban bármikor. Értem ez alatt az információdömpinget, amely a médiacsatornákon keresztuil zúdul ránk, a civilizációs ártalmakat és a változások rendszerét, mely körbevesz bennünket. A tartósan fennálló stresszhelyzetek károsíthatják a szervezetet. Ezekben a feladatlistákkal, szerepváltásokkal átitatott folyamatos nyomás alatt örvénylő hétköznapokban adhat hatékony segítséget a meditáció, amely egyfajta rekreáció, megújulás is egyben.
A meditációra tekinthetünk úgy, mint egyfajta ellazulásra, befelé figyelésre, elmélyedésre vagy elmélkedésre. Legfőbb célunk a lelki béke elérése, a pszichés ellazuláson és megnyugváson keresztül (Rogers,1980). A gyakorlatokat végezhetjük ülő vagy fekvő testhelyzetben.

Három technikát szeretnék ismertetni, az egyik egy egyszerú meditáció vagy relaxáció (http://meditacio.lap.hu/), a második egy autogén tréning, és végül a progresszív relaxáció zenével. Mindhárom nagyszerú megküzdési stratégia és megerősítés lehet a hétköznapokban, és segíthet céljaink elérésében, a belső harmónia és egyensúly megtalálása mellett. 


\section{IMEDITÁCIÓS TECHNIKÁK}

\section{EGYSZERÜ MEDITÁCIÓ}

Az egyszerú folyamat leírása és elvégzése a következó:

Hunyja be a szemét, majd vegyen mély lélegzetet! Néhány másodpercig tartsa bent a levegôt, majd amikor kifújja a levegőt, próbáljon ellazulni! Engedje, hogy ez könnyen menjen! Miközben kifújja a levegőt, érezze, hogy a feszültség távozik testéből! Most nyugtassa meg a légzését, és folyamatosan lazítsa el izmait, először a vállát, a karját, a felsőtestét, a lábát és minden egyes testrészét! Légzése laza és kiegyensúlyozott, az orrán szívja be a levegőt, és a száján fújja ki azt! Ez a lágy ellazult érzés folyamatosan szétárad testében. Kellemes meleg és súlytalanság érzéssel párosul. A folyamatot az ,egy” szócska folyamatos ismétlésével is végezheti (Bagdy és Koronkai, 1978). Pár perc múlva teljesen laza, kipihent, felfrissült állapotba kerül. A stresszes állapot elillan, mintha ott sem lett volna. Időtartam 5-10 perc.

Így sokkal kiegyensúlyozottabbá válik, és könnyebben hozza meg az optimális döntéseket.

A (medical) orvosi, vagy a (medicate) gyógyítani szavak jelentése hasonló a meditációhoz, tekinthetünk rá úgy is, mint egyfajta öngyógyító folyamatra (Hudson, 1996).

A meditáció segíthet a felvételi vizsgák során, sport- vagy egyéb szellemi versenyek, vetélkedők alkalmával, továbbá a vizsgaidőszakok alatt is. A tiszta gondolkodás, melyet a meditációs gyakorlatok végzése kapcsán tapasztalunk, segíthet a helyes és személyiségünkhöz illeszkedő célok kitûzésében, a belső motiváció megtalálásában, céljaink elérése érdekében (Roy, 2002).

Csinálhatjuk mozgás közben, futás, úszás, sétálás folytatása alatt is a meditációt, melyet megtámogathatunk instrumentális zene hallgatásával (Chinmoy, 2006), míg a masszázs alatti ellazulást illóolajok, illatgyertyák és a nyugodt környezet harmonizálja.

\section{AZ AUTOGÉN TRÉNING}

Az ,autogén” szó görög eredetú, a szótő az ,autos”, melynek jelentése ,ön”, a ,genos” jelentése pedig ,származás”, vagyis egy önmagunkból származó dolog. A ,tréning” szó pedig a gyakorlásra, trenírozásra utal (Acsai, 2009).

Lényegét tekintve saját erőből merítő, belső aktivitást felhasználó, rendszeresen végzett gyakorlat, amely egy ellazult, relaxált állapot elérése mellett, befelé koncentrálással, lelki kondicionálással párosul. A lelki kondicionálás történhet tréner utasításai alapján, vagy előre felvett hanganyag meghallgatása segítségével (Chinmoy, 1993).

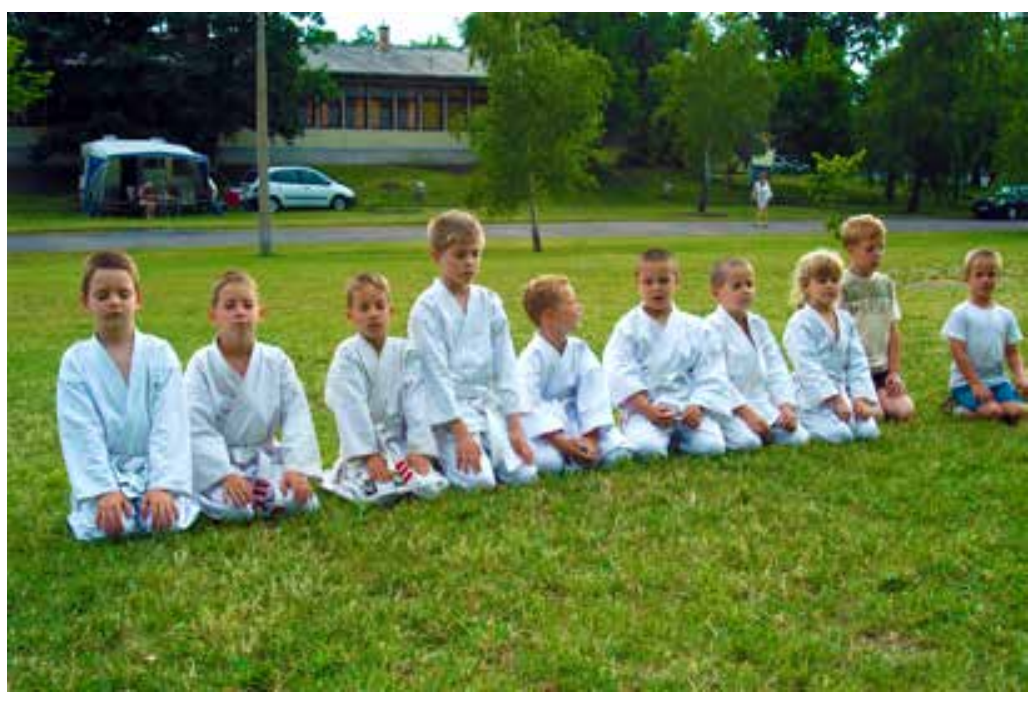

Az autogén tréning gyakorlati végrehajtása:

(Kermani, 1996)

Kényelmes testhelyzetet veszünk fel hasonlóan, mint az egyszerú meditációkor. Leülünk vagy lefekszünk, lehunyjuk szemünket.

Veszünk egy mély lélegzetet, majd lassan kifújjuk a levegót a tüdőből. Figyelünk rá, hogy lélegzésünk egyenletes és nyugodt legyen. Lélegzetvételek közben beszélünk testünk részeihez:

a. „Most ellazítom bal karomat, először a felkart, majd az alkart, végül a kézizmaimat. Bal karom most teljesen meleggé válik és elnehezül. Érzem, hogy ez kellemes, meleg érzés."

b. ,Most a jobb karom lazítom el, a felkarizmaimat, alkarom izmait és kezemet. Ez nagyon kellemes, meleg és lágy érzés."

c. „Most ellazulnak a bal lábam izmai, a combom elülső és hátulsó része, a farizmaim, a lábszárizmaim, végül a lábfejem és talpam valamennyi izma. Bal lábam most teljesen elnehezül és meleggé válik. Érzem, hogy ez kellemes, meleg érzéssel párosul."

d. ,Ellazítom a jobb lábam izomzatát, a combizmaimat elöl és hátul, majd farizmaim, lábszárizmaimat elöl és hátul egyaránt, végül a lábfejem és talpam izmait. Jobb lábam teljesen ellazult, lágy és meleg érzés árad szét benne."

e. "Ezután a törzsem izmait lazítom el, mellkasom és a hátam izomzatát. Teljesen ellazulnak a mellkasom, a hasam, az oldalam és a hátam izmai. Testem elnehezedik, melegség árasztja el a törzsem elöl és hátul, valamennyi izma."

f. ,Végül a fejem, arcom, nyakam és vállam izmait is ellazítom. Nagyon kellemes meleg és lágy érzés. Így testem teljesen ellazulttá válik. Melegség önti el teljes testem, ami nagyon jó érzés."

Minden belégzés után hatszor ismételjük a testrészek ellazítását célzó mondatainkat.

8-10 perc alatt teljesen ellazult állapotba kerültünk. Testünk így teljesen ellazult relaxált állapotba kerül, igen rövid idő alatt.

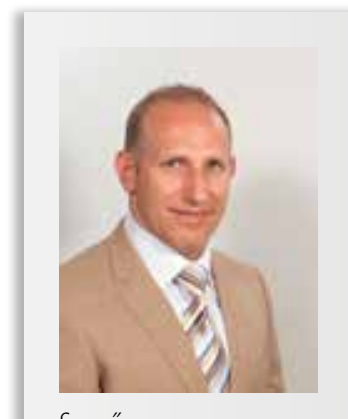

Szerző:

Mácsár Gábor rendốr alezredes, testnevelő tanár, küzdősport-szakreferens Munkahelye: Rendőrségi Oktatási és Kiképző Központ Rendészeti Szervek Kiképző Központ

További szerzők:

Bognár József

Eszterházy Egyetem Sporttudományi Intézet bognar.jozsef@ uni-eszterhazy.hu

\section{Plachy Judit} (szerkesztóséggel kapcsolattartó is) Miskolci Egyetem Egészségügyi Kar efkplachy@uni-miskolc.hu 


\section{MEDITÁCIÓ / TANULMÁNY}

Ez a technika rendkívül hatékony, mind a félelmeink leküzdésében, mind motivációs szintünk megemelésében (Réthyné, 2003), mind önbizalmunk megerősítésében, mind pedig a napi feszültség, idegesség és a kihívások kezelésében.

Alkalmazhatjuk továbbá motorikus képességek fejlesztésére vagy tanulási képességek javitására. Úgy is nevezzük, hogy önhipnózis módszere.

Tudatalatti énünk nem képes különbséget tenni az élénken elképzelt és a valódi élmények között. Ezen gyakorlat segítségével általános teljesítményünk javulni fog.

A meditáció során tudatunk relaxációs helyzetbe kerül, amit ,alfa állapotnak” is neveznek. Az ,alfa állapot” az ébrenlét és az alvás határán van. Felkészültté válunk a mély programozásra.

\section{A PROGRESSZIVV RELAXÁCIÓ ZENÉVEL}

Az agykutatás egyik Bulgáriában élő úttörője Georgi Lozanov volt (Tracy, 1993). Többek között azt is kutatta, hogy hogyan tanulhatnak gyorsabban és hatékonyabban az emberek. Káprázatos kutatási eredményeket ért el módszereivel, amely a „gyors tanulás” vagy „,szupertanulás” vagy a „tanulás a teljes aggyal” neveket kapta. Mindezt relaxációs, meditatív állapotban érte el.

Vizsgálatait az 1960-as, 70-es években folytatta. Módszereit felhasználva alakult ki a progresszív relaxáció zenével kombinált módszere. A zene jelentősége abban áll, hogy megnyitja a jobb és bal agyfélteke közötti kapcsolatot, így a heterogén kondicionálás, vagyis a korábban felvett és a relaxáció alatti pozitív állításainak meghallgatása közben, közvetlenül a tudatalatti énünkhöz jut el az információ. Ezek a pozitív állítások önmagukban is frissítőek, de ezenfelül igen gyors és hatékony személyiségváltozásokat eredményeznek.

A folyamat egy visszaszámlálással indul, amíg el nem érjük a teljesen ellazult állapotot, ekkor érkeznek a megerösítések ( $p l$. Könnyen emlékszel nevekre, helyekre és egyéb információkra! vagy Mindig magabiztos és határozott vagy!), és a gyakorlat végéhez közeledve, visszatérünk az éber állapotba egy újabb visszaszámolással. Ezt a meditációs formát is behunyt szemmel kell végezni.

Az ilyen jellegű hanganyagok rendszeres gyakorlása hatékony segítséget nyújt céljaink elérésében.

A relaxációt ne végezzük közvetlenül bőséges étkezés vagy ivás után. Javítja az eredményt, ha instrumentális zene, madárcsicsergés, vízcsobogás vagy más természeti hangok kíséretében, vagy természetben végezzük a gyakorlatot. Ennek az az oka, hogy a jobb és bal agyfélteke közötti kapcsolat megnyílik, és ezáltal eredményesebb lesz az ellazulás (Dahlke, 2002).

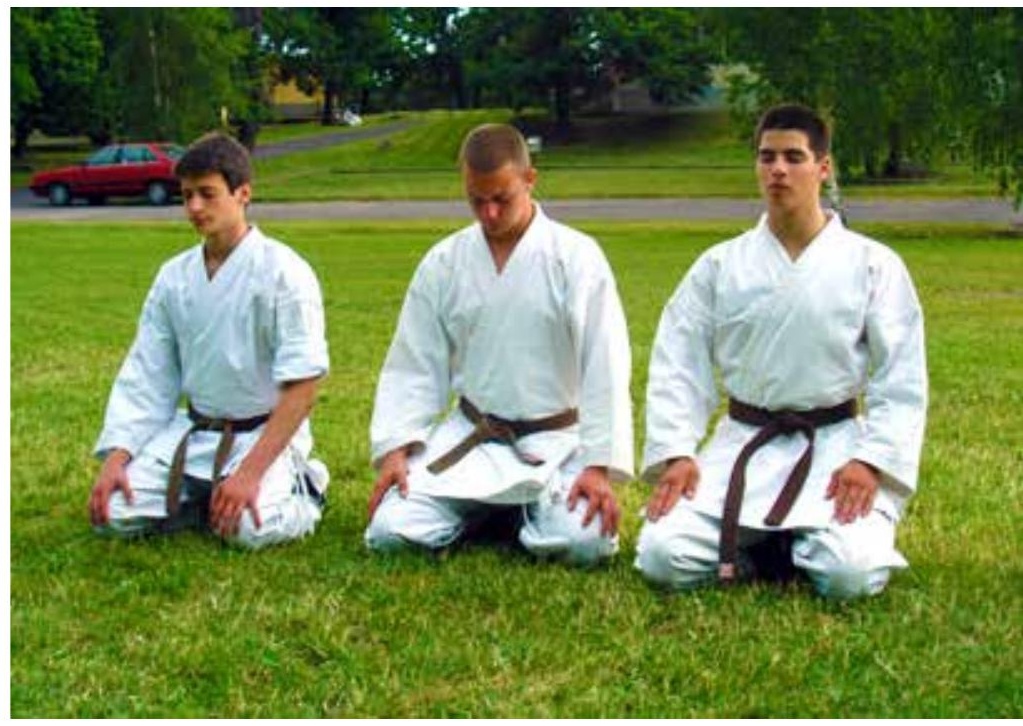

Összegzésként megállapítható, hogy a meditatív állapot elérésével a következö pozitív, jótékony hatások érik a relaxációt rendszeresen gyakorló embert:

- Javul önértékelésünk (Müller, 1996)

- A gyakorlás által könnyebben és gyorsabban tudunk ellazulni (Ben- Menachem, 1992)

- Megemelkedik az önbizalom szintje (Bagdy és Telkes J, 2000)

- Javul a döntéshozatali képesség, és ezen keresztül hatékonyabban választjuk meg céljainkat, karrierünk érdekében (Chinmoy, 2002)

- Csökken a stressz szintje (Hudson, 1996)

- Növekszik a koncentráció és tanulási képesség (NAT, 2012), így hat az eredményességre (Svensson, 1978)

- A kreativitás szintje is emelkedik (Révész és mtsai, 2005)

- Energetizálja a testet és a lelket (Plachy, 2015), ami motivációs szintünk emelkedéséhez (Szepes, 2002) és jobb kihasználtságához vezet (Pál, 2007)

- Oldja a stresszt és a feszültséget (Csíkszentmihályi, 2014)

- Könnyebben és tartósabban tudunk koncentrálni (Debreczeni, 1994)

- Nyugodtabban, kiegyensúlyozottabban reagálunk dolgokra (Bagdy, 2014)

- Az elménk hatékonyabban és élesebben funkcionál (Tolle, 2017)

- Csökken a vérnyomásunk és lelassul a szívverésünk (Plachy, 2015)

- A gyakorlat egészségmegőrző funkciójú (Gawler, 1987)

\section{GYAKORTATI TAPASZTATAT}

Tapasztalatom szerint a küzdősportedzések elején és végén lévő meditáció, ha az edző ezt tudatosan irányítva alkalmazza, jobb eredmények elérésére motiválja a tanítványokat. Erre korábban tettem kísérletet, és összehasonlításként az egykori Jugoszláviában is láttam példát. Röviden ismertetném megfigyelésemet.

A gyakorlat két ütésből és két rúgásból állt, monoton volt és mindenki számára egyértelmú. A két ismétlés között több mint fél év telt el. A koncentrációs képesség (fókusz és korrekt végrehajtás) és a kitartás tekintetében végzett közepes intenzitású, de nagy ismétlésszámú gyakorlatok 
végeztetésekor előzetesen felkészítettem tanítványaimat a feladatra. Ismertettem a feladatot és a terjedelmet is, valamint egy átlagosnál hosszabb irányított meditációt végeztünk. A motiváció szintje alig esett, a gyakorlat ismétlésszáma 1000 végrehajtás volt. A számolást a színes-övesek végezték, 50-es szériában, folyamatosan 20 fó. A gyakorlatok fókusza megmaradt a különböző korcsoportoknál és nemeknél.

Ugyanezt a gyakorlatot meditáció nélkül és a terjedelem ismertetésének hiányában végeztettem el. Az eredmény döbbenetes volt. A csoport szétesett, egyre többen és mind gyakrabban (kihagytak gyakorlatot, abbahagyták, gyengült a teljesítmény, esett a motiváció szintje stb.), egyszóval szétesett a csapatdinamika, továbbá néhányan leültek, és nem akarták végezni a „,céltalan" gyakorlatot.

\section{ÖSSZEGZÉS}

A példa jól szemlélteti a meditáció és a célkitűzés hatásának néhány értékes tulajdonságát, mely támogatja az egyetemekre felvételizô vagy éppen vizsgáikra készülő hallgatók körét éppúgy, mint a pályamotivációt és karriercélok kialakítását. A kiválasztási folyamat lefolytatóit is segítheti a helyes és hatékony döntéshozatalban (Bognár, Trzaskoma-Bicsérdy, Révész, 2009).

\section{FELHASZNÁLT}

\section{IRODALOIM JEGYZÉTE}

Acsai Irén (2009): Az élsport, sporttehetség, tehetséggondozás. In Szatmári Z. (szerk.): Sport, életmód, egészség. Akadémiai Kiadó, Budapest. 485-486.

Bagdy E, Kádár A., Kozma-Vízkeleti D., Pál F., Szondy M. (2014): Bízz magadban! Kulcslyuk Kiadó, Budapest.

Bagdy E. (2014): Relaxáció, megnyugvás, belső béke. Kulcslyuk Kiadó, Budapest. Bagdy E; Telkes J. (2000): Személyiségfejlesztô módszerek az iskolában. Nemzeti Tankönyvkiadó,

Bagdy-Koronkai (1978): Relaxációs módszerek, Medicina, Budapest.

Ben-Menachem, M. (1992): Lazíts az életedért! Courier Részvénytársaság, Budapest.

Bognár J., Trzaskoma-Bicsérdy G., Révész L. (2009): A kiválasztás. In Szatmári Z. (szerk.): Sport, életmód, egészség. Akadémiai Kiadó, Budapest. 733-739.

Tracy B. (1993): Maximális Teljesítmény. ford. Doubravszky Sándor, Bagolyvár Kiadó, Budapest. 113-114.

Csíkszentmihályi M. (2014): Az öröm múvészete. Libri Könyvkiadó, Budapest.

Dahlke M., Dahlke R. (2002): Meditációs kalauz. Budapest: Bioenergetic Kft.,

Debreczeni L. (1994): A tiszta tudat.

Budapest: Édesvíz Kiadó

Tolle E. (2017): The Power of Now (A most hatalma a gyakorlatban) ford: Tótisz András, Édesvíz Kiadó

Gawler I. (1987): A lélek csendje. Melbourne: Hill of Content Kiadó

Hudson J. (1996): Instant meditation for stress relife. The New Life Library, (Gyors meditáció) Alexandra Kiadó, Pécs
Kermani, K. (1996): Autogén Tréning. Maecenas Könyvek, Budapest.

Müller P. (1996): Benső mosoly. Budapest: Édesvíz Kiadó

Nemzeti alaptanterv (2012): Kompetenciafejlesztés.

Pál, F. (2007): A szorongástól az önbecsülésig. Kulcslyuk Kiadó, Budapest.

Plachy J. (2015): Phd. anyag: „A rendszeres fizikai aktivitás hatása az idős kori függetlenség megőrzésére 60 év fölötti nők esetében: randomizált kontrollált kísérlet"

Réthy E.-né (2003): Motiváció, tanulás, tanítás. Nemzeti Tankönyvkiadó, Budapest.

Révész L., Bognár J., Géczi G.,

Benczeinleitner O. (2005): Tehetség meghatározása, sportágválasztás és kiválasztás három sportágban. Magyar Sporttudományi Szemle, 4. 17-23.

Rogers, C. R. (1980): A személyiség és viselkedés elmélete. In: Személyiséglélektani Sz. Gy. II. (szerk. Szakács F; Kulcsár Zs.) Tankönyvkiadó, Budapest.

Roy,V. (2002): Relaxáció az iskolában. Szakdolgozat. Eötvös Loránd Tudományegyetem

Sri Chinmoy: Meditáció. Az ember tökéletessége Isten elégedettségére. Budapest: Madal Bar,

Sri Chinmoy (2006): Meditáció. Budapest: The Golden Store Ezoterika Kft., 1993. Sri Chinmoy (2002): Meditációs technikák. Budapest: Madal Bar, 2002.

Svensson, E. (1978): Mood: Its structure and measurement. Psychological reports, no. 6, vol 8, University of Göteborg, Sweden.

Szepes M. (2002): Aranykor, Plátói

világhajnal. Budapest: Édesvíz Kiadó, 2002.

Online:

http://meditacio.lap.hu/

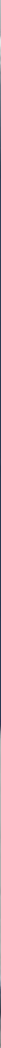

